\title{
希少呼吸器疾患の治療・管理
}

\author{
谷本 安*, 谷本光音
}

岡山大学病院 呼吸器・アレルギー内科

キーワード : 希少疾病用医薬品, 特発性間質性肺炎, 特発性肺線維症, ピルフェニドン

\section{The care of rare respiratory diseases in Japan}

\section{Yasushi Tanimoto*, Mitsune Tanimoto}

Department of Allergy and Respiratory Medicine, Okayama University Hospital

\section{はじめに}

呼吸器系の希少疾患で近年臨床試験が活発に行われ ているものとしては, 特発性肺線維症（idiopathic pulmonary fibrosis：IPF）やリンパ脈管筋腫症, 自己 免疫性肺胞蛋白症などがあげられる. 感染症や肺高血 圧症を除いた呼吸器領域において, 希少疾病用医薬品

（オーファンドラッグ）の指定を受けて上市されてい る薬剤は, IPF の治療薬であるピルフェニドン (PFD) のみである。本稿では, IPF の病態と治療について, 特にPFDの薬理作用や臨床効果を中心に述べる.

\section{特発性間質性肺炎の分類・診断基準と特発性肺線維症 の病態}

特発性間質性肺炎(idiopathic interstitial pneumonias： IIPS）は，おもに胞隔を炎症・線維化病変の場とする 疾患である間質性肺炎の中で, 原因が特定できないも のの総称であり, 厚生労働省特定疾患に指定されてい る. 全国の特定疾患医療受給者証交付数は2005年度以 降，4,000〜5,000を推移している. IIPsには 7 つの病 型があるが，そのうち IPF は頻度が最も高く，かつ予 後不良な疾患である。慢性進行性の経過をたどり，高 度の線維化が進行し, 不可逆性の蜂巣肺形成をきたす 難治性疾患であり, 診断時からの平均生存期間が概ね 5 年とされている. 2000年に米国胸部疾患学会 (ATS) から発表されたIPF のコンセンサスステートメント， 引き続いて2002年に発表されたATS/欧州呼吸器学会 （ERS）によるIIPs 分類のステートメントにより，

平成 23 年 2 月受理

* $7700-8558$ 岡山市北区鹿田町 2-5-1

電話：086-235-7226 FAX : 086-232-8226

E-mail : ytanimot@md.okayama-u.ac.jp
IIPs の国際的な分類・診断基準となるものが策定さ れた。我が国においても2003年に ATS/ERS ステート メントとの整合性をもって IIPS の分類・診断基準の 第 4 次改訂がなされ, 2004年に「特発性間質性肺炎 診 断と治療の手引き」が日本呼吸器学会から発行され た ${ }^{1)}$ IIIPs の確定診断には，膠原病や薬剤など原因の 明らかな間質性肺炎や他のびまん性㓌影を呈する疾患 を除外することが重要である，さらに，原則として外 科的肺生検による病理組織診断に基づくが，IPF に限 っては高分解能 CT (HRCT) によって蜂巣肺等の典 型的所見が確認できる場合, 病理組織診断なしに診断 可能とされている(図 1 ).

IPF の原因は不明であるが，種々の外因的，あるい は内因的刺激により肺胞上皮や基底膜が傷害され，そ の修復過程における線維芽細胞の増殖や細胞外マトリ ックスの過剩な増生によって線維化病変が形成され, 肺の硬化により呼吸機能障害が惹起される ${ }^{2)}$ 。これま で，IPF の生存率や QOL に対する有効性が明確に証 明された薬物療法はなく, 進行性に悪化するIPFに対 して, 副腎皮質ステロイドと免疫抑制薬（シクロフォ スファミド, アザチオプリンなど）の併用が推奨され てきた。しかしながら，これらはいずれも炎症過程の 抑制作用が主体であり，線維化を阻止または改善する ものではなかった。従って, IPFの治療には, 抗炎症 作用のみならず，慢性進行性の線維化を抑制する作用 のある薬片が望まれてきた。近年, PFD やインターフ エロン- $\gamma$ な゙の抗線維化薬, あるいは $\mathrm{N}-$ アセチルシ ステイン $(\mathrm{NAC})$ などの抗酸化薬が治療薬として注目 されている(図 2 ). 


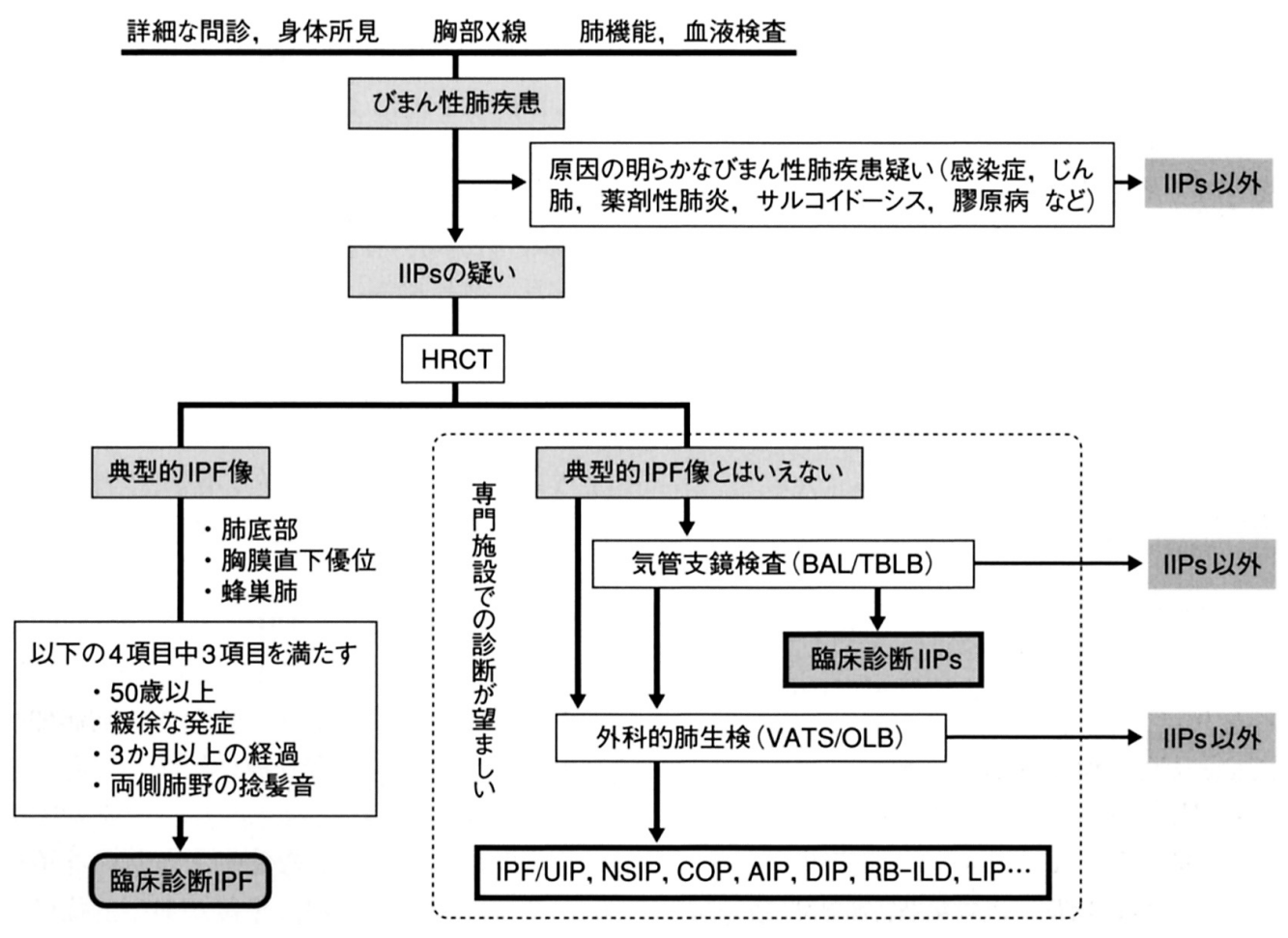

図 1 第 4 次改訂の特発性間質性肺炎（IIPS）診断のアルゴリズム（文献 1 より）

IPF : 特発性肺線維症, UIP : 通常型間質性肺炎, NSIP：非特異性間質性肺炎, COP：特発性器質化肺炎, AIP：急性間質性肺炎, DIP：剥離性間質性肺炎, RB-ILD：呼吸細気管支炎を伴う間質性肺疾患, LIP：リン パ球性間質性肺炎, HRCT：高分解能 CT, BAL：気管支肺胞洗浄, TBLB：経気管支肺生検, VATS：胸腔 鏡下肺生検, OLB：開胸肺生検

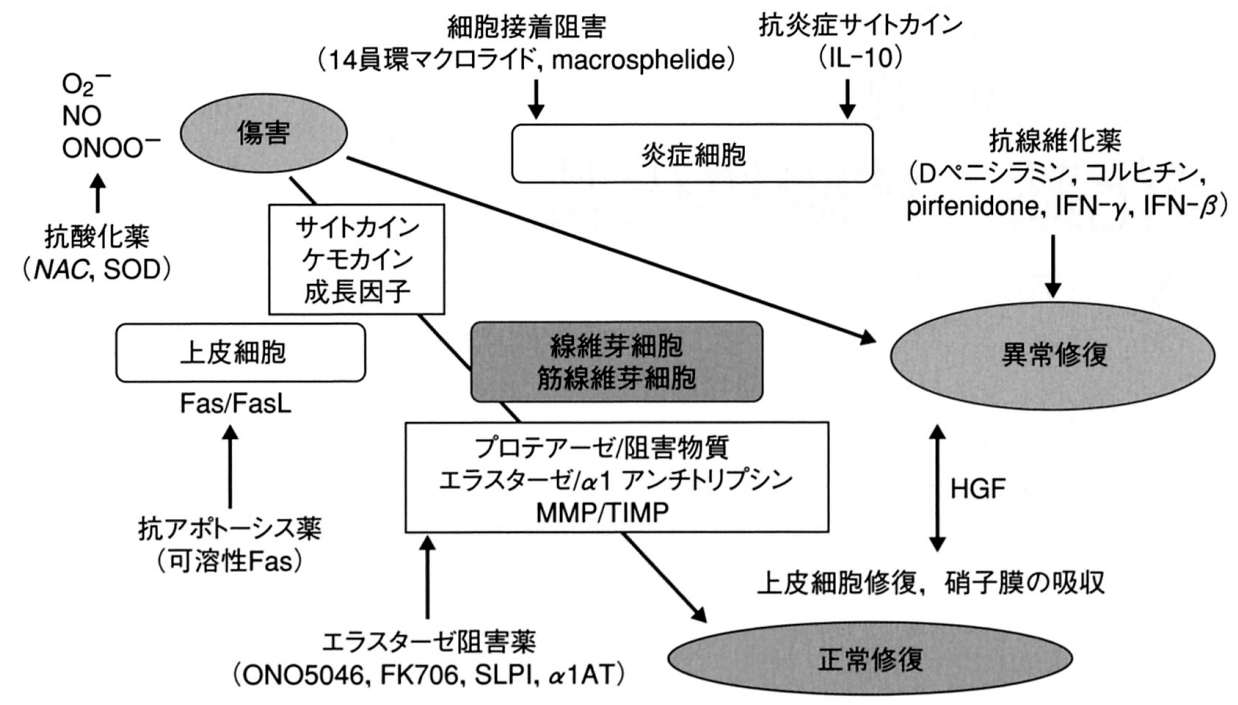

図 2 肺線維症の新しい治療戦略図 一 肺傷害から修復・再構築 一（文献 2 より） 


\section{抗線維化薬：ピルフェニドン（PFD）}

\section{1. 開発の経緯}

PFD は IPF の治療薬として世界に先駆け我が国で 認可された抗線維化薬である。米国の Marnac 社で開 発された低分子化合物（図 3 ）で, シクロオキシゲナ 一ゼを抑制しない抗炎症薬として開発が開始された。 その途上で炎症モデルとして検討されたイヌ肺感染症 モデルに拈いて抗線維化作用を有することが見出さ れ，以後はIPF の治療薬として開発が進められた ${ }^{3)}$. 我が国においても IPF の治療薬として臨床試験が行 われ，2008年10月に上市された。

\section{2 . 薬理作用}

動物実験では, ブレオマイシン誘発肺線維症モデル, 肝硬変モデル, 腎線維化モデルなどで, PFD が各臓器 における線維化の抑制と機能低下の抑制をもたらすこ とが確認されている ${ }^{4,5)}$. PFD 投与によってこれらのモ デルでは組織中の TGF- $\beta$ mRNA の発現が抑制される ことが示されている. また, エンドトキシン誘発急性 炎症モデルでは TNF- $\alpha$ 産生抑制作用が認められ, TGF- $\beta$ と TNF- $\alpha$ の産生抑制が PFD の抗線維化作用 において特に重要な役割を果たしていると考えられて いる.肺線維症モデルでは, PFD の抗線維化作用は主 にTGF- $\beta$ やPDGF などの増殖因子の産生抑制による とされている。また，IFN- $\gamma$ の低下を抑制する作用も 重要と考えられている.

\section{3 . 臨床試験成績}

米国のパイロット研究では, 努力肺活量の低下抑制 が認められた 。これに基づいて，我が国でも無作為 化比較試験が実施された。国内第 II 相試験では PFD $(1,800 \mathrm{mg} /$ 日） が肺活量（VC）の低下抑制と急性増悪 の抑制をもたらすことが示された ${ }^{6)}$. 国内第正相試験 では，IPF 患者267名を対象にPFD のプラセボに対す る優越性を二重盲検層別無作為化並行群間比較試験で 比較し, 主要評価項目をVCとし, 重点副次評価項目 を無増悪生存期間と労作時 $\mathrm{SpO} 2$ 最低值として評価さ

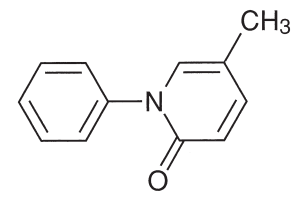

図 3 ピルフェニドンの化学構造
れた ・VCの変化量は，プラセボ群と PFD 高用量群 $(1,800 \mathrm{mg} /$ 日) , 低用量群 $(1,200 \mathrm{mg} /$ 日) との間で有意 差が認められ，PFDは VCの低下を抑制することが 示された（図 4 ）。無増悪生存期間も PFD 高用量群で はプラセボ群との間に有意差が認められたが, 労作時 $\mathrm{SpO} 2$ 最低值の変化量については有意差が認められな かった。

副作用は高用量群で $88.1 \%$, 低用量群で78.2\%に認 められた。プラセボ群と比較して有意に発現率の高か ったものは, 光線過敏症 $(51.7 \%)$, 胃腸障害（食欲不 振 $23 \%$, 胃不快感 $14 \%$, 嘔気 $12 \%), \gamma$-GTP 上昇 $(20 \%)$ で，副作用による薬剤の中止は高用量群で $15.6 \%$ ，低 用量群で $9.1 \%$ であった.当初光線過敏症が問題視され たが，外出時に強力な日焼け止め $(\mathrm{SPF}$ 值 $50+, \mathrm{PA}$ 值 $+++）$ を使用することで対処可能である。むしろ本 薬剤の規定因子は食欲不振などの消化器症状とされて いる．継続服用することが治療上重要であるので， $1,800 \mathrm{mg} /$ 日で消化器症状が強く出る場合には $1,200 \mathrm{mg} /$ 日で維持することも考慮すべきである.

\section{おわりに}

2008年末に世界に先駆けて日本発の IPF 治療薬ピ ルフェニドンが発売された。すでに 2 年余りが過ぎ, IPF 治療が様変わりしてきており，「手引き」の改訂も 予定されている。国内第正相試験の开ブ解析では，軽 症の早期症例により有効であることが示唆されてい る。しかしながら，どういった患者に真に有効である のか，他剤との併用効果はどうなのか，まだ明確な答 えは得られておらず，これからの課題である。

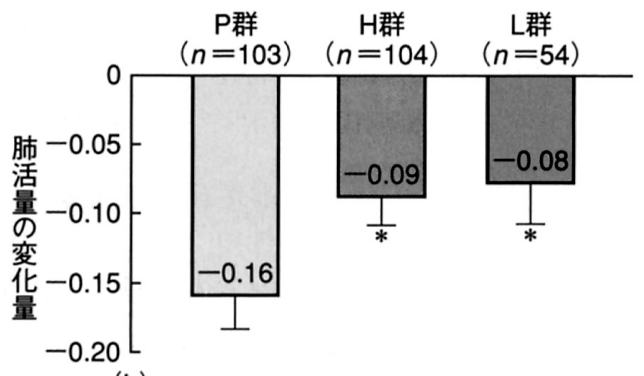

(L)

図 4 ピルフェニドン (PFD) 第正相試験の結果：肺活量 (VC) の変化量 (文献 7 より)

$\mathrm{P}$ 群：プラセボ群, $\mathrm{H}$ 群：ピルフェニドン $1,800 \mathrm{mg} /$ 日群, L 群： ピルフェニドン $1,200 \mathrm{mg} /$ 日群

* : p $<0.05$ (vs P 群, 共分散分析) , mean $\pm \mathrm{SE}$ 


\section{文献}

1 ）特発性間質性肺炎 診断と治療の手引き, 日本呼吸器学会び まん性肺疾患診断・治療ガイドライン作成委員会編, 南江 堂, 東京 (2004).

2 ) 桑名正隆: 肺線維症の発症機序. 医学のあゆみ (2004) 211, 1063-1067.

3) Raghu G, Johnson WC, Lockhart D, Mageto Y : Treatment of idiopathic pulmonary fibrosis with a new antifibrotic agent, pirfenidone : results of a prospective, open-label Phase II study. Am J Respir Crit Care Med (1999) 159, 1061-1069.

4) Bhatt N, Baran CP, Allen J, Magro C, Marsh CB : Promising pharmacologic innovations in treating pulmonary fibrosis. Curr Opin Pharmacol (2006) 6, 284-292.

5 ) Lasky JA, Ortiz LA: Antifibrotic therapy for the treatment of pulmonary fibrosis. Am J Med Sci (2001) 322, 213-221.

6) Azuma A, Nukiwa T, Tsuboi E, Suga M, Abe S, Nakata K, Taguchi Y, Nagai S, Itoh H, Ohi M, Sato A, Kudoh $\mathrm{S}$ : Double-blind, placebo-controlled trial of pirfenidone in patients with idiopathic pulmonary fibrosis. Am J Respir Crit Care Med (2005) 171, 1040-1047.

7 ) Taniguchi H, Ebina M, Kondoh Y, Ogura T, Azuma A, Suga M, Taguchi Y, Takahashi H, Nakata K, Sato A, Takeuchi M, Raghu G, et al. ; Pirfenidone Clinical Study Group in Japan: Pirfenidone in idiopathic pulmonary fibrosis. Eur Respir J (2010) 35, 821-829. 